\title{
The Use of Collaborative Design Thinking in Improving Student Writing Skill
}

\author{
Karimah Robiatul Addawiyah \\ Universitas Muhammadiyah Jakarta, Indonesia \\ (karimahrobiatuladdawiyah@gmail.com)
}

\begin{abstract}
Writing is still considered a difficult skill to master. Problems arise from various aspects of writing namely grammar, vocabulary, types of text, outline, and so on. Tackling these problems is possible with appropriate teaching method. The Collaborative Thinking Design Method (CoDeT) was chosen as an effective and innovative method to help students improve students' writing skills as this encouraes them to be active in the learning process and discuss with classmates. The purpose of this study was to determine whether there was a significant improvement in the use of CoDeT method in students' writing skills. Using the VII grade students of MTs AT-Tawazun Subang in year 2019/2020 as population, this study used quantitative methods with experimental research design. The average values obtained in the Pre- and post-test were 52.73 and 91.92, respectively. This means that Tcount $>$ ttable or $4.01>3.06$, with the result that students' writing skills are enhanced using Collaborative Design Thinking (CoDeT) method instead of the conventional method. This means that there is a significant improvement in the inclusion of Collaborative Design Thinking (CoDeT) method on students' writing skills. It implies that CoDeT method can enhance students' ability to teach writing skills in narrative texts. Through this research, several advantages of using the Collaborative Design Thinking (CoDeT) method in teaching writing skills to seventh grade students were revealed, such as 1). encouraging students to be actively involved in the learning process and 2). facilitating students in understanding teaching material through discussion.
\end{abstract}

Keywords: Design thinking; writing; quantitative.

The role of teachers is important especially in developing students' writing skills. Robinson et al., (2019) pointed out that if the students' writing foundation is built strongly, the teacher believes that they will write well and correctly. In a similar belief, Dreyfus et al. (2020) also mentioned how important paying attention to students' writing skills. This is due to the process of writing that does not only require mastery of word writers, use 
of punctuation, and choice of words.

Nowadays, teaching English writing

is considerably needed as students are demanded to have an ability to communicate with and actively participate in the global society (Mutiarani et al,. 2019). Since 2013 English has been a compulsory subject in the Indonesian national curriculum of secondary school. As apart of English subject competences, the teaching writing is thereafter deal with several genres of description, recount, narrative, and report text. In Indonesia, an English teacher practically runs the learning writing process on the basis of a government syllabus. For example, in writing narrative texts, students are required to have an ability to compose their own stories in a narrative form.

Meanwhile, English teaching writing needs to more concerned, as Khanza \& Nufus, (2019) reported that most teachers are still experienced difficulty to prepare students on writing demand. In his research finding, Cortes (2019) also argues that most students participate in a writing class passively, such as students' last row sitting, bored feeling, etc. Based on the following definition and issue, the researcher concludes that the teacher needs to improve the quality of teaching writing in a meaningful way to develop students' abilities in the writing process.

However, in reality, $60 \%$ of students still at MTs At-Atawazun tend to experience difficulties in the writing process, mainly in the narrative text that typically uses a constructive format that describes the sequence of nonfiction-fiction events. Along with this, the confusion about the generic structure of narratives and language features also affected students' interest in writing narrative text so far. In this case as generally based on observation result, these problems can be influenced by a number of possible causes. The first cause possibly is that the monotonous learning activity given by the teacher in class and this is why students feel bored. In addition, the students' lack of getting relevant resources has led students' inability to effectively develop critical thinking on narrative text composition ideas. This cause is also corroborated by a statement that has been scrutinized by White et al,. 2015), "writing is neglected in the early grades, even though the data consistently show that many students struggle in this area". Lastly, the students are also less enthusiastic to develop narrative text due to the lack of teachers' feedback on their written work. Therefore, it makes difficult for students to decide whether the text they are making has followed the topic question.

The urgency of the researcher used Collaborative Design Thinking (CoDeT) because the learning methods that are set are different from the learning methods applied in other schools in other schools where teachers are active in the learning process, and students are only as audiences in the learning process. In other words, the teacher is the controller with students as the object to receive the material explained in the learning process. This is assumed to be the cause of students' boredom, looking exhausted, lacking of motivation, and not paying attention in class. Such negative attitude if remains may affect the quality of students in learning English.

Referring to the above writing problems, the researcher is interested to use Collaborative Design Thinking (CoDeT) method weekly to be a creative problemsolving on students' writing narrative text. Then, regarding to its implementation, five writing stages are used, which are sparked by Mechelen et al, 2019, they are empathize, define, ideate, prototype, and test. In essence, there were some researchers that specifically showed how the CoDeT method significantly improves students' development in learning. A study conducted by (Huq \& Gilbert, 2017) found that the CoDeT method has succeeded in creating a pleasant learning environment and minimizing barriers between student and teacher gaps. Surely, the cultural diversity that involves one's worldview may be demanding, disruptive, and emotionally challenging. By 
using CoDeT or collaborative method, this can effectively help EFL students to write better and more accurate paragraphs, rather than by individuals in which educators are demanded to be creative in presenting the material (McDonough et al., 2018).

Moreover, the result of similar researches was also carried out by Helldorff et al., (2020), where through exploring the CoDeT method, students are actively involved in content discussions, technical communication, and language negotiations as part of the language learning process. In addition, this method also empowers and contributes to students' satisfaction and learning outcomes. Referring to the background of the study, Vieluf \& Göbel, (2019) argued that foreign language teachers need to find better ways to increase all students' interest and involvement during the lesson.

Viewing the process, writing is recognized to be more complex than other language skills. It involves the process of conveying thoughts, presuppositions, feelings, in accordance with writing. Alongside this statement, Ueasiriphan \& Tangkiengsirisin (2019) further summarized that writing is a process that allows somebody to organize their ideas collectively and provide opportunities to evaluate their own writing individually. Therefore, the researcher chose to use the Collaborative Design Thinking method in improving students' writing skills to help students understand teaching materials by way of collaboration and discussion with classmates and be more active in the learning process.

According to (Leverenz, 2014) and (Watson, 2015), CoDeT is one of the innovative methods that can provide students with the creative and personalized teaching writing process in a collaborative way. It provides a cyclical process that supports students' creativity and autonomy in composing a paragraph. As stated by (Van Mechelen et al., 2019), the Collaborative Design Thinking (CoDeT) method was popularized by David Kelley and Tim Brown, the founder of IDEO's international design consulting firm. The method is actually a combination of two methods namely Cooperative Learning and Design Thinking. Students' involvement in their learning is likely to be marked by the response they give to researchers of course, actively asking if they do not understand what they are studying, trying to find answers freely by talking with their friends and asking teachers if the brand doesn't feel right get answers to their questions(Hadi \& Emzir, 2016)

As explained by (Henriksen et al,. 2017), Collaborative Design Thinking (CoDeT) is a method that directs creativity towards writing goals and involves students' abilities to respond with significant solutions to factual problems. By emphasizing the collaborative learning system, (Isjoni, 2014) believes that this method can be an appropriate way to create student-centered learning and to establish cooperation and interdependence in the tasks, goals, and achievements. In consonant with Isjoni's belief, Collaborative Design Thinking $(\mathrm{CoDeT})$ provides a strategy that effectively and efficiently to maximize learning circumstances to achieve learning goals particularly in teaching writing (Laferriere et al,. 2019) Based on these explanations, it can be concluded that Collaborative Design Thinking (CoDeT) is a learning method used by teachers in order to create an effective and innovative educational setting. Through the implementation of small or collaborative groups, students can efficiently build good collaboration in completing writing assignments given by the teacher.

Relying on its advantages, (Mosely et al,. 2018) points out that the implementation of Collaborative Design Thinking (CoDeT) has several benefits so far.

1. Building collaboration between team As a process, CoDeT allows each student in groups to gives respect, enables to share writing skills or knowledge, and builds a writing habit to develop students' creativity and autonomy. 2. Creating space to generate ideas productively Several studies that have implemented CoDeT have proven that students' writing productivity increases. During the writing process, students 
actively participate in constructive discussion and together generate ideas productively.

3. Increasing students writing skill

It is found that the CoDeT method can reduce students' difficulties during the writing process. At the same time as generating ideas, each student in a team also instills empathy with other students in a team. Empathy in the process of creating creative solutions is needed so that fellow team members can voice their ideas and get rid of their egos by feeling the most right.

\section{Method}

This research was conducted online. There is no question that technology has changed the world view of education from ordinary models to computers (Izzah and Hadi, 2019). The method used in this study is a quantitative method with experimental research designs. This is a research method used to look for specific treatment effects in numbers or statistically analyzed (Creswell, 2014). Pre-experimental research has two designs including one-shot case studies and one pretest-posttest design group. The method used in this study is a quantitative method with an experimental research design.

In addition, this study specifically used a pre-experimental research design, where the aim is to find out the cause and effect between two factors that are intentionally caused in this study. Referring to this type of design, research is focused on One Group of Pretest-Post-test Design. It is hoped that the results of treatment can be known more accurately because of the collaboration of the two conditions, before being given treatment and after being given treatment. This design used one group that already exists. One class is taken as an experimental group. Data collected from writing skills tests (pre-test and post-test), as primary data, were analyzed using the t-test formula with a computational system to find out whether there was a significant influence using Collaborative Design Thinking (CoDeT) as a method of teaching English in writing skills

\section{Results and Discussion}

In this section, the researcher will explains the collected data during the study conducted at Mts At-Tawazun Subang. The sample of this study was students at the 7th graders. In the first meeting, all 27 students were given a pre-test to measure their narrative writing skills. After the process of collecting pretest data, the researcher prepared the teaching materials and implemented Collaborative Design Thinking (CoDeT) to improve students' writing skills. The treatment was conducted for seven meetings. At the last meeting, the researcher gave the post-test. The results of the two tests were used as a reference for the author to analyze the students' improvement in writing skills.

Prepares the teaching materials and uses Collaborative Design Thinking to enhance students' writing skills. Care was taken during the seven meetings. At the last meeting, the author gave a post exam. The results of both tests serve as a reference point for the author to analyze the students' improvement in writing skills test.

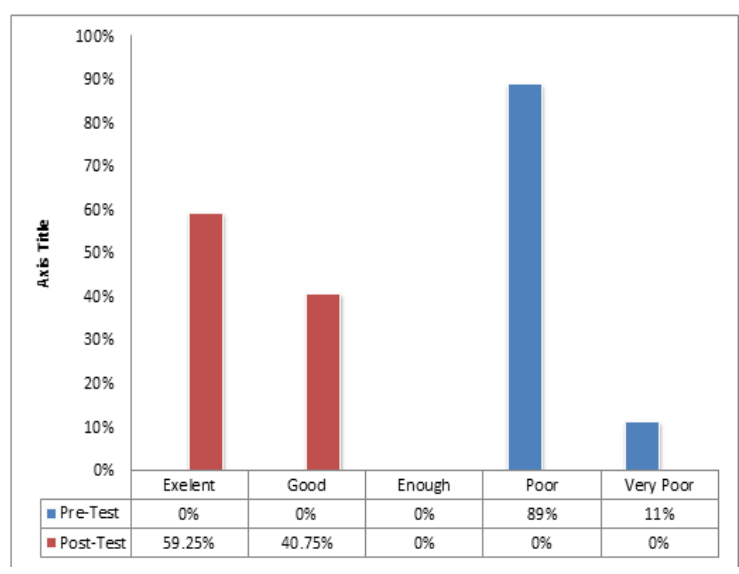

Figure 1. The result of pre-test and post-test 


$$
\begin{aligned}
& \qquad \begin{aligned}
\bar{D} & =\frac{1059}{27}=39.22 \\
\operatorname{Variance}\left(S^{2}\right) & \\
& =\frac{1}{n-1} \sum_{1=1}^{n}((X j-X i) \\
& -\bar{D})^{2}
\end{aligned}
\end{aligned}
$$$$
=\frac{1}{26}(67.133)
$$

$$
\begin{aligned}
S D=\sqrt{\text { Variance }} & \\
& =\sqrt{2.582} \\
& =50.81 \\
& t=\frac{\bar{D}}{\frac{S D}{\sqrt{n}}} \\
= & \\
& \\
= & \\
& \frac{39.22}{\sqrt{27}}
\end{aligned}
$$

The calculation above explains that the yield of t0 4.01 and ttable with degrees of freedom (df) 27 yields 3.06. The mean value is less than 0.05 and for table $>t$ table. This means that Collaborative Design Thinking (CoDeT) is effective in improving students' writing skills.

Based on the results of the pre-test and the post-test students above, the researchers analyzed the results to find out the students' writing skills in narrative texts using the Collaborative Design. Researchers calculated based on the t-test formula steps as follows. The calculation above explains that the yield of t0 4.01 and ttable with degrees of freedom (df) 27 yields 3.06. The mean value is less than 0.05 and for table $>\mathrm{t}$ table. This means that Collaborative Design Thinking is effective in improving students' writing skills.

In a previous study by $\mathrm{McD}$ onough et al. (2018) in Belgium with the title Collaborative Design Thinking (CoDeT): A collaborative design approach for high ratio of young adults. 49 children aged between 9 and 10 years. This study has a similar title but has differences in the methods of data collection, teaching materials, and also research samples. In previous studies the school for this investigation was chosen deliberately. One school is a Catholic school located in an urban area, and the other is a public school located in the suburbs.
School selection aims to offer a diverse mix of children from social, ethnic and personal backgrounds. . In this arrangement, children must work independently of the adult who is the driver next door. This can be a challenge due to children's limited understanding of the design process and their lack of skills to collaborate productively towards shared design goals. CoDeT overcomes these challenges by integrating the principles of Social Interdependence Theory and Design Thinking, which together form the core of approach theory. CoDeT was first introduced in case studies and produced promising results in terms of children's collaboration and design thinking skills.

In this study, the researcher used one class with English material writing skills especially Narrative text and the data collection of this study used pre-test and post before and after treatment. Through this research, several advantages of using the Collaborative Design Thinking (CoDeT) method in teaching writing skills to seventh grade students were revealed as follows 1). this method can encourage students to be actively involved in the learning process. 2). the method can facilitate students in understanding teaching material by means of discussion.

\section{Conclusion}

Based on the study of seventh graders at MTs AT-Tawazun, it can be concluded that using the Collaborative Design Thinking method can improve students' writing skills. This is reflected in student test results after the Collaborative Design Thinking method is applied where the post-test scores are higher than their pre-test scores.

The analysis results of this study obtained t0 (t-observation) 4.01, while $\mathrm{t}$ (table t-table) was 3.06 with a significant $5 \%$ which means that $\mathrm{t} 0$ ( $\mathrm{t}$-observation) is higher than $\mathrm{tt}$ (t-table). From the above explanation, it can be concluded that writing teaching skills using Collaborative Design Thinking in the seventh 
grade AT-Tawazun are effective in improving students' writing skills.

English is a foreign language subject taught at school. Students assume that English is difficult to understand. Students tend to be less interested in learning it. The ability to speak English consists of four abilities, namely listening, reading, speaking and writing. Teachers as educators students in the class must have teaching methods that can facilitate students in understanding teaching material specifically in writing skills. Collaborative Design Thinking (CoDeT) method is one of the teaching methods that can improve students' writing skills to improve. Because students can collaborate with each other to discuss about the material that the teacher teaches, especially about narrative text. Seeing the results of the research and conclusions above, it can be stated Collaborative Design Thinking (CoDeT) method in learning English seventh grade students MTs At-Tawazun can improve students' English proficiency in writing skills. In addition to the ability to speak English, there are also factors that influence the mastery of English. These factors come from within students (internal) and from outside students (external).

From the results of the study, it can be concluded that in using the Collaborative Design Thinking (CoDeT) method can improve English language skills in students' writing skills.

\section{References}

Cortes, V. (2019). Considering the Importance of L2 Learners' Writing Needs. Journal of Second Language Writing. https://doi. org/10.1016/j.jslw.2019.100679

Creswell, J. W. (2014). Research design: Qualitative, quantitative, and Mixed Methods Approaches. SAGE Publications, Incorporated. Research Design: Qualitative, Quantitative, and Mixed Metod Approaches. (pp. 22-236). Lincoln: University of Nebraska
Hadi, M. S., \& Emzir, E. (2016). Improving English Speaking Ability through Mobile Assisted Language Learning (MALL) Learning Model. IJLECR - International Journal of Language Education and Culture Review. https://doi.org/10.21009/ ijlecr.022.09

Henriksen, D., Richardson, C., \& Mehta, R. (2017). Design Thinking: A Creative Approach to Educational Problems of Practice. Thinking Skills and Creativity. https://doi.org/10.1016/j.tsc.2017.10.001

Huq, A., \& Gilbert, D. (2017). All the world's a stage: Transforming Entrepreneurship Education Through Design Thinking. Education and Training. https://doi. org/10.1108/ET-12-2015-0111

Isjoni. (2014). Cooperative Learning Efektifitas Pembelajaran Kelompok. https://doi. org/10.1038/nmeth.2839.A. (pp.16-20). Bandung: Alfabeta.

Khanza, M., \& Nufus, T. Z. (2019). The Effect of Scaffolding toward Students' Writing Procedure Text. English Language in Focus (ELIF). https://doi.org/10.24853/ elif.2.1.33-42

Laferriere, R., Engeler, B., \& Rixon, A. (2019). Addressing Cognitive Challenges in Applying Design Thinking for Opportunity Discovery: Reflections from a Design Thinking Teaching Team. She Ji. https://doi.org/10.1016/j. sheji.2019.11.012

Leverenz, C. S. (2014). Design Thinking and the Wicked Problem of Teaching Writing. Computers and Composition. https:// doi.org/10.1016/j.compcom.2014.07.001

Izzah, L \& Hadi, M.S. (2019). Engaging Learners with the Internet of Things (IoT): Gen Z's Perspectives. Educational Initiatives Research Colloquium 2019.

McDonough, K., De Vleeschauwer, J., \& Crawford, W. (2018). Comparing the Quality of Collaborative Writing, 
Collaborative Prewriting, and Individual Texts in a Thai EFL Context. System. https://doi.org/10.1016/j. system.2018.02.010

Mosely, G., Wright, N., \& Wrigley, C. (2018). Facilitating Design Thinking: A Comparison of Design Expertise. Thinking Skills and Creativity. https:// doi.org/10.1016/j.tsc.2018.02.004

Robinson, J., Dusenberry, L., Hutter, L., Lawrence, H., Frazee, A., \& Burnett, R. E. (2019). State of the Field: Teaching with Digital Tools in the Writing and Communication Classroom. Computers and Composition. https://doi. org/10.1016/j.compcom.2019.102511

Ueasiriphan, T., \& Tangkiengsirisin, S. (2019). The effects of genre-based teaching on enhancement of Thai engineers' technical writing ability. International Journal of Instruction. https://doi.org/10.29333/ iji.2019.12246a

Van Mechelen, M., Laenen, A., Zaman, B., Willems, B., \& Abeele, V. Vanden. (2019). Collaborative Design Thinking (CoDeT): A co-Design Approach for High Childto-Adult Ratios. International Journal of Human Computer Studies. https://doi. org/10.1016/j.ijhcs.2019.06.013

Vieluf, S., \& Göbel, K. (2019). Making Intercultural Learning in EFL Lessons Interesting - the Role of Teaching Processes and Individual Learning Prerequisites and Their Interactions. Teaching and Teacher Education. https:// doi.org/10.1016/j.tate.2018.11.019

Watson, A. D. (2015). Design Thinking for Life. Art Education. https://doi.org/10.1080/ 00043125.2015.11519317 
